\title{
Cimetidine, an unexpected anti-tumor agent, and its potential for the treatment of glioblastoma (Review)
}

\author{
FLORENCE LEFRANC $^{1}$, PAUL YEATON ${ }^{3}$, JACQUES BROTCHI $^{1}$ and ROBERT KISS ${ }^{2}$ \\ ${ }^{1}$ Department of Neurosurgery, Erasmus University Hospital, ${ }^{2}$ Laboratory of Toxicology, \\ Institute of Pharmacy, Université Libre de Bruxelles, Brussels, Belgium; \\ ${ }^{3}$ Department of Gastroenterology, University of Virginia, Charlotesville, VA, USA
}

Received November 2, 2005; Accepted December 29, 2005

\begin{abstract}
Cimetidine (CIM), the prototypical histamine $\mathrm{H} 2$ receptor antagonist (H2RA), was brought to market based on its ability to accelerate healing of gastrointestinal ulcers through the inhibition of gastric acid secretion. Cimetidine, the most studied H2RA, has been demonstrated to possess anti-tumor activity against colon, gastric and kidney cancers, and melanomas. This activity involves a number of different mechanisms of action: a) CIM antagonizes tumor cellmediated interleukin-1-induced activation of selectins in liver sinusoids, inhibiting tumor cell binding on liver sinusoids, thereby reducing the development of liver metastasis; b) histamine acts as a growth factor in various tumor cell types via the activation of $\mathrm{H} 2$ receptors; CIM therefore may antagonize this effect; c) CIM acts as an immunomodulator by enhancing the host's immune response to tumor cells. With respect to malignant gliomas, CIM added to temozolomide was superior in vivo when compared to temozolomide alone in extending survival of nude mice with human glioblastoma cells orthotopically xenografted into their brain. We review the various mechanisms of action potentially associated with the therapeutic effects of CIM in the case of experimental glioblastomas, observations we hope will encourage clinical investigation of CIM in the management of highly malignant gliomas.
\end{abstract}

\section{Contents}

1. Origin of cimetidine

2. Initial therapeutic indications of cimetidine

Correspondence to: Dr Robert Kiss, Laboratory of Toxicology, Institute of Pharmacy, Université Libre de Bruxelles, Campus de la Plaine, Boulevard du Triomphe, 1050 Brussels, Belgium

E-mail: rkiss@ulb.ac.be

Abbreviations: CIM, cimetidine; H2RAs, histamine $\mathrm{H} 2$ receptor antagonist

Key words: cimetidine, H2RAs, malignant gliomas, cancer
3. Cimetidine as an anti-tumor drug

4. Mechanisms of action of cimetidine in oncology

5. Cimetidine and malignant gliomas

6. Conclusions

\section{Origin of cimetidine}

Cimetidine [N"'-cyano-N-methyl-N'-(2)((5-methyl-1Himidazol-4-yl)methyl)thio)ethyl)guanidine] is a substituted imidazole with a specific antagonistic effect on histamine $\mathrm{H} 2$ receptors. Briefly, cimetidine (CIM) is a weak base with a high level of water solubility which can be measured in biological fluids including the cephalo-spinal fluid (1). CIM is metabolized in the liver by oxidative hydroxylation and conjugation. Up to $80 \%$ of a single dose of CIM is excreted in the urine (1), with up to $70 \%$ in an unchanged form (1). Its principal action is on parietal cell histamine $\mathrm{H} 2$ receptors, and by binding to these receptors, inhibits gastric acid secretion stimulated by histamine, pentagastrin, acetylcholine, insulin, food and other secretagogues (2).

\section{Initial therapeutic indications of cimetidine}

CIM was the first registered histamine H2RA, its wide acceptance was based on its clinical effectiveness in the healing of gastrointestinal ulcers through inhibition of gastric acid secretion (1-3). CIM was one of the most widely used H2RA during the 1980s (3). At the time of its introduction in the late 1970s, CIM was rarely considered an agent with clinical utility other than its primary indication (3). A primary concern was if by virtue of their acid-inhibitory activity, H2RAs increased the risk of developing gastrointestinal malignancies (3); tiotidine, one of the earliest H2RAs developed, was abandoned when preclinical toxicity tests demonstrated an increased incidence of gastric tumors in rats (4). CIM inhibits several isozymes of the cytochrome P450 enzyme system, including CYP1A2, CYP2C9, CYP2C19, CYP2D6, CYP2E1, and CYP3A4. This inhibition forms the basis of the numerous drug interactions. While CIM proved to be a safe medication, its use in peptic ulcer disease was supplanted by the development of longer-acting H2RAs with reduced adverse effects and the introduction of highly specific proton pump inhibitors (2). 
Table I. Description of the various clinical trials using cimetidine in oncology.

\begin{tabular}{|c|c|c|c|c|c|}
\hline $\begin{array}{l}\text { Oncological } \\
\text { indication }\end{array}$ & $\begin{array}{l}\text { Type of } \\
\text { trial }\end{array}$ & $\begin{array}{c}\text { Cimetidine } \\
\text { dose }\end{array}$ & $\begin{array}{l}\text { No. of pts. } \\
\text { enrolled }\end{array}$ & $\begin{array}{c}\text { Results } \\
\text { (patient survival) }\end{array}$ & Authors/Refs. \\
\hline Gastric cancer & Randomized & Post-operative $800 \mathrm{mg} / \mathrm{d}$ & 181 & Significant increase & Tonnesen et al (6) \\
\hline Gastric cancer & Randomized & $1-1.2 \mathrm{~g} / \mathrm{d}$ & 65 & Significant increase & Burtin et al (5) \\
\hline Colorectal cancer & Randomized & $5 \mathrm{~d}$ pre- $/ 2 \mathrm{~d}$ post-operative $800 \mathrm{mg} / \mathrm{d}$ & 34 & Significant increase & Adams and Morris (7) \\
\hline Colorectal cancer & Randomized & $5 \mathrm{FU}+/$-post-operative $800 \mathrm{mg} / \mathrm{d}, 1 \mathrm{y}$ & 64 & Significant increase & Matsumoto (8) \\
\hline Colorectal cancer & Randomized & Post-operative $400 \mathrm{mg}$ twice $/ \mathrm{d}, 2 \mathrm{y}$ & 45 (Dukes C) & Significant increase & Svendsen et al (9) \\
\hline Colorectal cancer & Randomized & Pre-operative, $7 \mathrm{~d}$ & 42 & 3-y survival benefit & Adams and Morris (10) \\
\hline Colorectal cancer & Randomized & Pre-operative $800 \mathrm{mg}$ twice $/ \mathrm{d}, 5 \mathrm{~d}$ & 125 & Survival benefit & Kelly et al (11) \\
\hline Colorectal cancer & Non-randomized & $5 \mathrm{FU}+/$-post-operative $800 \mathrm{mg} / \mathrm{d}, 1 \mathrm{y}$ & 64 & 10 -y survival benefit & Matsumoto et al (13) \\
\hline Advanced melanoma & Phase II & $300 \mathrm{mg}, 4 \mathrm{x} / \mathrm{d}$ & 19 & $1 \mathrm{CR}, 2 \mathrm{PR}$ & Morton et al (16) \\
\hline Advanced melanoma & Phase II & $\mathrm{INF}+1.2 \mathrm{~g} / \mathrm{d}$ & 35 & $7 \mathrm{PR}$ & Creagan et al (15) \\
\hline Metatastatic RCC & Non-randomized & Coumarin $+300 \mathrm{mg}, 4 \mathrm{x} / \mathrm{d}$ upd & 42 & $3 \mathrm{CR}, 11 \mathrm{PR}$ & Marshall et al (17) \\
\hline Metatastatic RCC & Phase II & Coumarin $+300 \mathrm{mg} \mathrm{4x/d}$ & 50 & $4 \mathrm{PR}$ & Dexeus et al (18) \\
\hline Metatastatic RCC & Non-randomized & $600 \mathrm{mg} / \mathrm{d}$ upd & 42 & $2 \mathrm{CR}$ & Inhorn et al (19) \\
\hline Metatastatic RCC & Phase III & $\mathrm{INF}+/-($ coumarin $+400 \mathrm{mg} \mathrm{3x/d})$ & 148 & No significant increase & Sagaster et al (20) \\
\hline
\end{tabular}

upd, until progression of disease; d, day; y, year; CR, complete response; PR, partial response; INF, interferon; RCC, renal cell carcinoma.

\section{Cimetidine as an anti-tumor drug}

The first reports suggesting CIM exhibited a clinical oncologic effect appeared in 1988 in the context of gastric cancer $(5,6)$. In a randomized study including 65 patients selected because their condition contraindicated all other forms of treatment, Burtin et al (5) found that a course of CIM (1-1.2 g/ day) or ranitidine (450-900 mg/day) significantly improved the patients' survival rates. These patients survived six times longer than others receiving palliative treatment with analgesics (5). Another multicenter, randomized, double-blind, placebocontrolled study carried out by Tonnesen et al (6) on 181 patients showed that a post-operative course of CIM at a normal therapeutic dosage $(800 \mathrm{mg} /$ day $)$ significantly prolonged the survival of gastric cancer patients.

In colorectal cancer patients, Adams and Morris (7) were the first to demonstrate the beneficial effect of a short-course perioperative treatment with CIM on surgically-induced immunosuppression. Their randomized study involving 34 patients showed a strong trend towards enhanced survival in the patients treated with CIM ( $800 \mathrm{mg} /$ day) when compared to controls, a finding correlated with an increase of lymphocyte infiltration into the tumors (7).

Matsumoto (8) performed a multicenter randomized controlled study in 64 colorectal cancer patients receiving postoperative 5-fluorouracil. Post-operative treatment with CIM $(800 \mathrm{mg} /$ day $)$ and 5 -fluorouracil $(150 \mathrm{mg} /$ day $)$ for about a year was efficacious, increasing the disease-free period and survival when compared to the treatment with 5-fluorouracil alone (8).

Several subsequent studies, summarized in Table I, have been published showing considerably enhanced survival rates in gastric and colorectal cancer patients treated with CIM (9-13).
The use of CIM also has intriguing implications in the management of advanced malignant melanomas (14-16) and metastatic renal cell carcinomas (17-20) (Table I).

Our group (21) has demonstrated that CIM complements the cytotoxic agent temozolomide in experimental glioblastomas, a point detailed in the section entitled Cimetidine and malignant gliomas.

\section{Mechanisms of action of cimetidine in oncology}

Studies of the anti-tumor effects of CIM indicate multiple potential mechanisms of action, characterized by three overall characteristics: a) a direct inhibitory effect on tumor growth by blocking the cell growth-promoting activity of histamine (22-24) (Fig. 1) and an indirect effect by inhibiting tumorassociated angiogenesis (Fig. 2) (25); b) a cell-mediated immunomodulation by enhancing the host's immune response to tumor cells (Fig. 1) (26-28); c) an inhibition of cancer cell migration (21) and adhesion to endothelial cells (29) and therefore an inhibition of tumor neo-angiogenesis (25) (Fig. 2) and metastasis development (29) (Fig. 3).

Inhibitory effects on tumor growth. While the mechanisms involved are incompletely understood, CIM is known to inhibit the growth of several types of tumors, including gastrointestinal cancers, both in vitro and in vivo in animal models $(23,24)$. An active role is strongly suggested for histamine of autocrine or paracrine origins in malignant cell proliferation (Fig. 1) (12).

Histamine is a receptor-dependent growth factor in some, but not all, human colon cancer cell lines, as well as in some gastric, breast and melanoma cell lines $(23,24,30,31)$. In a culture study of four different colorectal tumor cell lines 


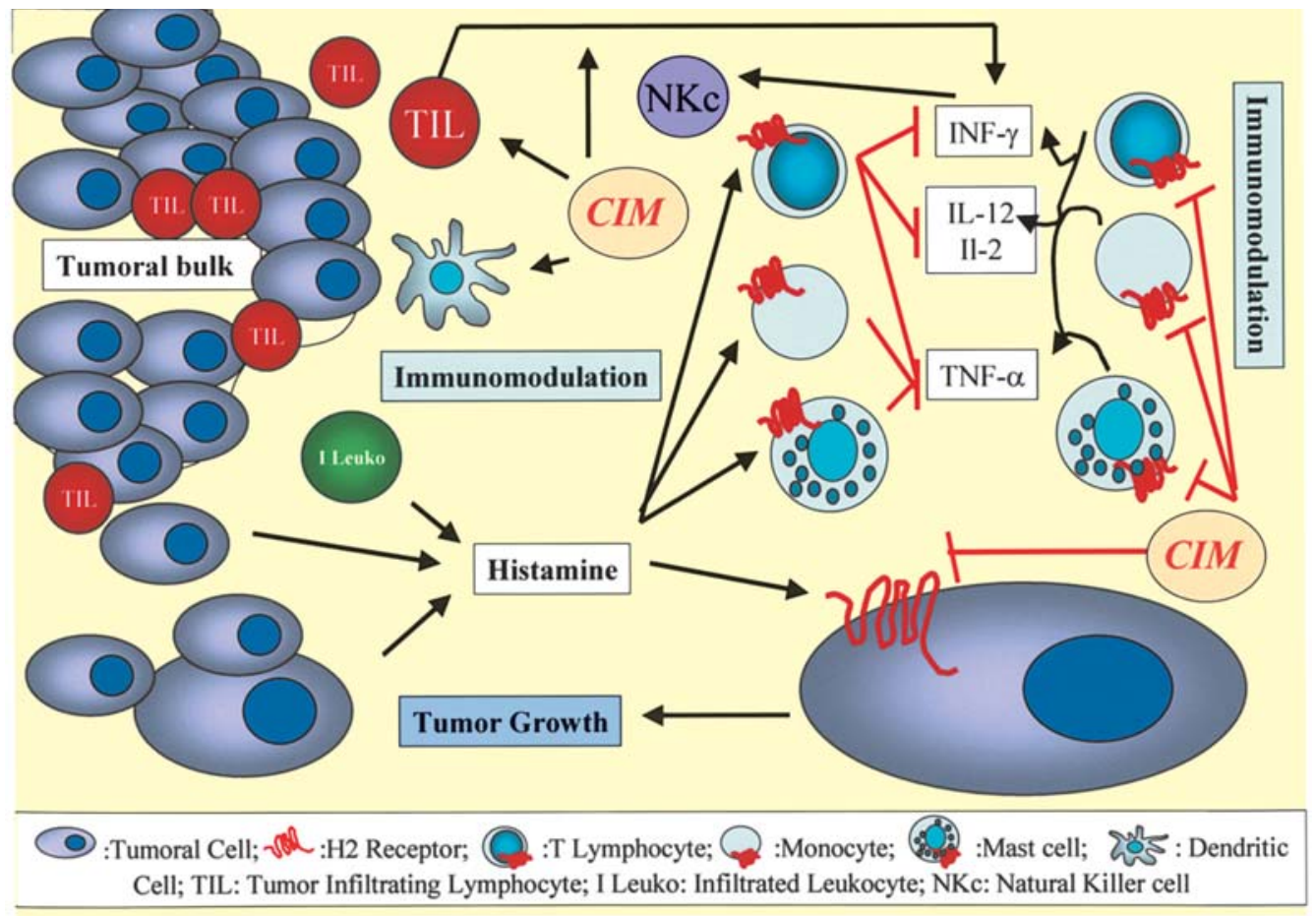

Figure 1. CIM inhibitory effect on tumor growth and CIM-mediated immunomodulation. CIM blocks the cell growth-promoting activity of histamine. The mechanisms proposed for the cell-mediated immunomodulation of CIM include the inhibition of suppressor T lymphocyte activity, the stimulation of natural killer cell (NKc) activity, an increase in interleukin-2 (IL-2) and interleukin-12 (IL-12) production in helper T lymphocytes, an increase in tumor inhibitory cytokines and the enhancement of the host's anti-tumor cell-mediated immunity.

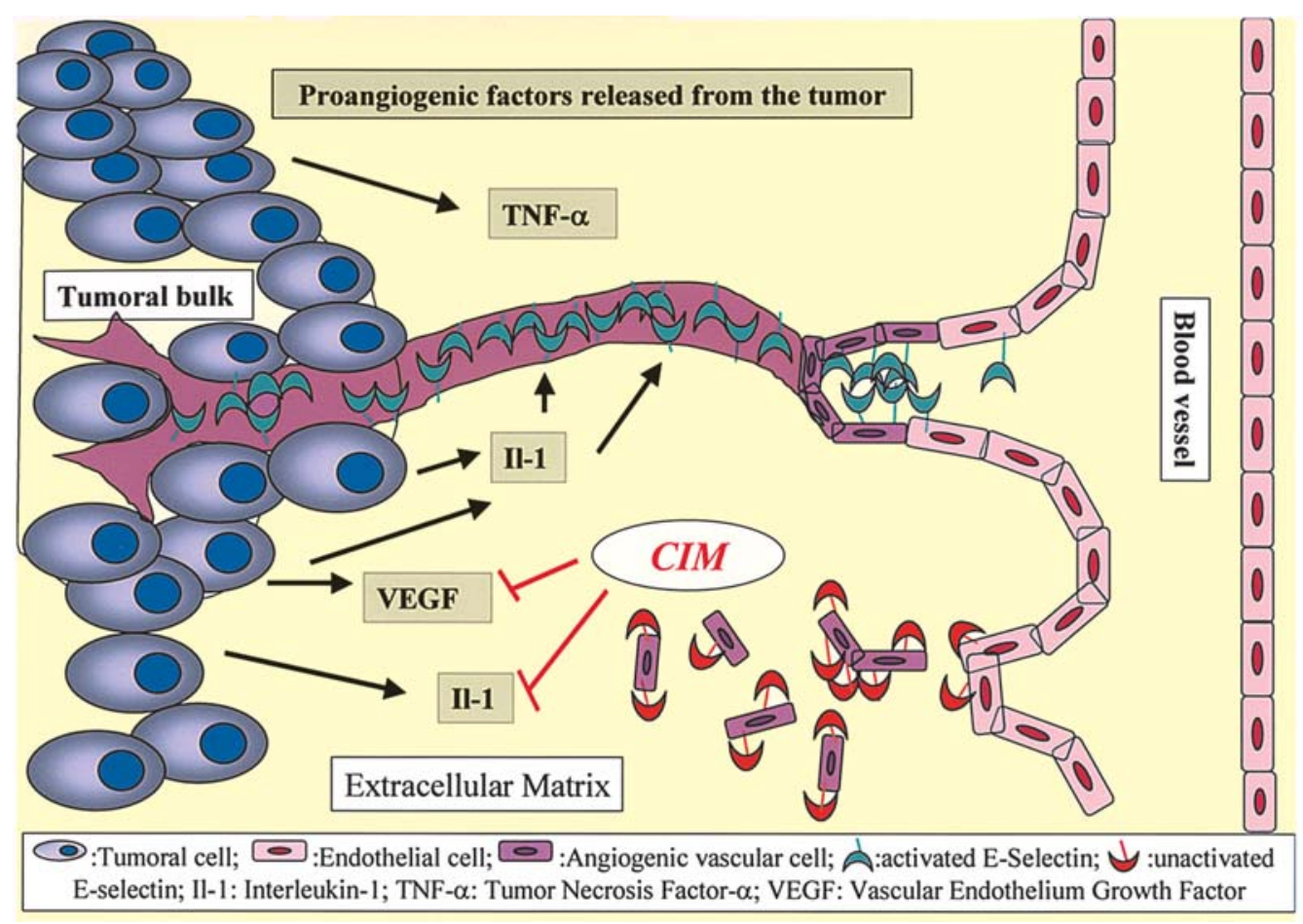

Figure 2. CIM-mediated neo-angiogenesis inhibition. CIM induces a significant decrease in VEGF expression levels and the vascular-like tube formation by endothelial cells is significantly impaired.

(C170, Lovo, LIM2412 and LIM2405) histamine was found to stimulate cell proliferation in two of them $(\mathrm{C} 170$ and LIM2412) in a dose-dependent manner (23). This effect was reversed by CIM in the presence of histamine, but not in its absence (23). When the $\mathrm{C} 170$ cell line was grown in nude mice as a subcutaneous xenograft, CIM had a significant dose-dependent growth-inhibitoring effect leveling out at a dose of $50 \mathrm{mg} / \mathrm{kg} /$ day (23). 


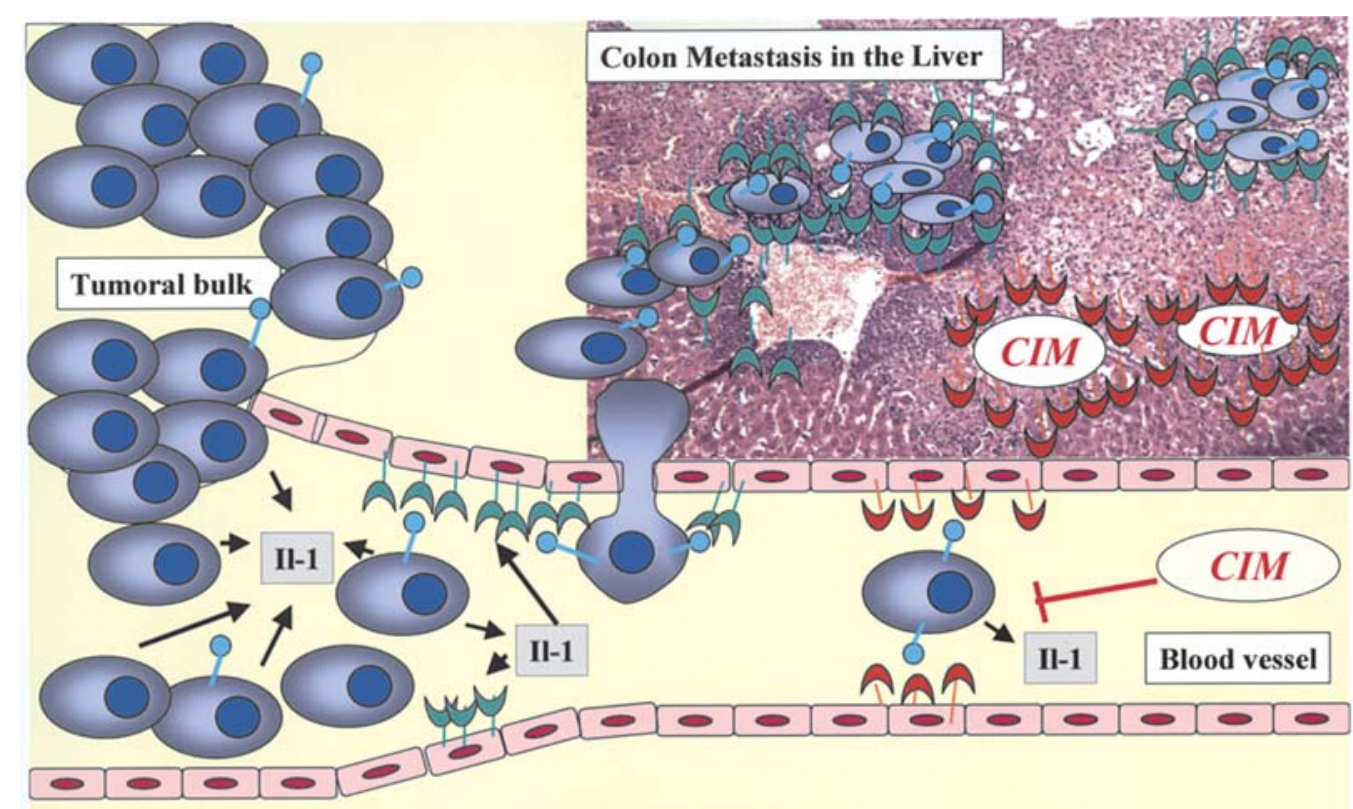

:Tumoral cell; $\bigcirc$ :Endothelial cell; $\mathcal{h}$ :activated E-Selectin; $\downarrow$ :unactivated E-selectin $9:$ Lewis Antigen

Figure 3. CIM-mediated inhibition of cancer cell migration and the development of liver metastasis. Epithelial cells detaching themselves from primary epithelial tumors (tumoral bulk) and migrating through the lymphatic or the blood vessels eventually colonize the liver because epithelial cancer cells exhibiting Lewis antigens on their surfaces are able to adhere to endothelial cells in liver sinusoids due to the presence of selectins (the ligands for Lewis antigens) in these endothelial liver cells. CIM prevents liver metastasis of colon cancer cells by blocking E-selectin activation by means of the inhibition of interleukin-1 (IL-1) secretion by the tumor cells.

Rajendra et al (32) demonstrated that CIM at $10 \mu \mathrm{M}$ inhibited the in vitro proliferation of the Caco-2 colorectal cancer cell line in the presence of histamine by causing apoptotic cell death. In the human gastric tumor cell lines MKN45 and MKN45G, CIM $(10 \mu \mathrm{M})$ reversed the histamine-stimulated proliferation (30). CIM also inhibited the proliferation of MKN45 subcutaneous xenografts in nude mice $(100 \mathrm{mg} / \mathrm{kg} /$ day, given in the drinking water) (30). In another in vitro study, histamine significantly stimulated cells proliferating in a dose-dependent manner on the gastric cancer cell lines KATO-III and AGS, with the maximum effect again occurring around a $10 \mu \mathrm{M}$ concentration (31). CIM reversed the histamine-stimulated cell proliferation, with the maximum effect at concentrations above $10 \mu \mathrm{M}$ (31). Ranitidine and famotidine did not show such an effect (31). Histamine significantly stimulated growth in two of four human melanoma cell lines, and this effect was inhibited by CIM in a dose-dependent manner, and also by ranitidine and famotidine (24). CIM also inhibited tumor growth of human pancreatic cancer xenografts in immunodeficient mice (33).

Adams et al (23) suggested a role for $\mathrm{H} 2$ receptors located either on the tumor cells themselves, on immunocompetent cells in the host, or both. Using L-histidine decarboxylase (HDC)-deficient mice with undetectable levels of endogenous histamine, Takahashi et al $(34,35)$ have shown that the daily administration of CIM $(0.12 \mathrm{mg} / \mathrm{kg} / \mathrm{day})$ failed to suppress the growth of a syngeneic colon adenocarcinoma despite the fact that an identical dose of CIM suppressed tumor growth in wild-type mice, as the result of the inhibition of the H2-mediated actions of endogeneous histamine. Curiously, ranitine did not seem to exert most of the in vitro and in vivo effects mentioned, an observation which would argue against $\mathrm{H} 2$ receptors playing a role in the effects of CIM, since ranitine is marginally more potent as an $\mathrm{H} 2$ receptor antagonist (36). In fact, in a prospective randomized controlled study, the use of ranitidine in patients with gastric cancer did not show any significant increase in their survival rates (37). In contrast, roxatidine significantly decreased the in vivo growth of colon 38 implants in mice (38). In their study, Tomita et al (38) showed that in vitro, histamine, roxatidine, and CIM failed to achieve any growth-promotive or suppressive effects in the case of the colon 38 cell line, a cell line that lacks $\mathrm{H} 2$ receptors, although roxatidine and CIM suppressed the in vivo growth of the tumor tissue implants. Such a finding suggests that in this case, the tumor-suppressive effects of $\mathrm{H} 2$ receptor antagonists do not constitute the product of any direct action on tumor cells. Szincsak et al (39) have shown that in vivo tumor proliferation in immunodeficient mice xenotransplanted with a human melanoma cell line was diminished by CIM $(50 \mathrm{mg} / \mathrm{kg} /$ day $)$, if combined with a tamoxifen derivate acting on cytochrome $\mathrm{P} 450$ molecules. This suggests again that the effect of CIM cannot be restricted to an $\mathrm{H} 2$ receptor blocker alone. The anticancer actions of CIM might not be mediated via histamine antagonist only. Therefore, the mechanisms of action by which CIM prolongs the survival of patients with various forms of cancer remain to be clarified and are probably multifactorial. The inhibitory effect of CIM on tumor-associated angiogenesis $(25,38)$ is developed below. 
Cell-mediated immunomodulation. Many tumors, and particularly colorectal and breast cancer, secrete histamine, a process that results in high histamine levels within the tumors $(13,40)$. Moreover, histamine is also frequently secreted in response to the surgical resection of colorectal cancers (40). All these factors working together create an immunosuppressive environment both in the area of tumor growth and in the whole body, and in so doing they facilitate tumor growth. A number of clinical studies have shown that the administration of CIM may help in reducing the immunosuppression due to increased histamine levels in a tumor's environment $(11,41)$. Adams and Morris (7) first desribed that pre-operative treatment with CIM ( $800 \mathrm{mg} /$ day) significantly increased the proportion of colorectal cancers that elicited a lymphocyte response, and that the presence of tumor-infiltrating lymphocytes was associated with a survival advantage. In a pilot study, they showed that CIM enhanced the lymphocyte infiltration of human colorectal carcinomas (10). Forty-two patients scheduled for the elective resection of colorectal carcinomas were randomized either to receive CIM for one week preoperatively, or to act as control (10). A positive lymphocyte response was observed in 10 of 18 CIM-treated carcinoma patients compared with only 5 of the 24 control patients $(\mathrm{p}=0.03)$ (10). Moreover, the presence of a lymphocyte response correlated with improved survival (10). Gastric cancer patients also have higher levels of suppressor lymphocyte activity when compared to normal controls, and these levels are restored to normal with CIM treatment (42). In a controlled randomized clinical trial, Lin et al (43) recently showed that pre-operative CIM administration at the dose of $400 \mathrm{mg}$ /day promoted peripheral blood lymphocytes and tumor infiltrating lymphocytes in patients with gastrointestinal cancer.

The mechanisms proposed for the cell-mediated immunomodulation of CIM (Fig. 1) include the inhibition of suppressor T lymphocyte activity (26), stimulation of natural killer (NK) cell activity (27), an increase in interleukin-2 (IL-2) production in helper T lymphocytes (28), an increase in tumor inhibitory cytokines (35) and the enhancement of the host's anti-tumor cell-mediated immunity by improving the suppressed dendritic cell function in advanced cancer patients (44).

Takahashi et al (35) have demonstrated that: a) a daily injection of CIM suppressed tumor progression in mice after the syngeneic transplantation of CT-26 cells (a colon adenocarcinoma cell line); and b) decreased expression of TNF- $\alpha$ and INF- $\gamma$ associated with the tumor development was restored following treatment with CIM. CIM dramatically increased IFN- $\gamma$ production by human lymphocytes (Fig. 1) via a possibly histamine-independent (non-histamine receptor mediated) pathway, most likely through cytochrome P450 moieties (45). High concentrations of INF- $\gamma$ resulted in the inhibition of cell proliferation by the direct stimulation of natural killer cells (Fig. 1) (45). The use of CIM also retarded the growth of human melanomas in a nude mouse model and prolonged the survival of the tumor-bearing mice by directly inhibiting the proliferation of tumor cells and indirectly promoting the infiltration of activated macrophages into the tumor site (39). It is also reported that H2RAs such as CIM can reverse the inhibition of the secretion of human interleukin-12 (IL-12) induced by histamine via $\mathrm{H} 2$ receptors expressed on monocytes (the precursors of dendritic cells) (Fig. 1) (46). While it remains unclear whether or not $\mathrm{H} 2$ receptors are expressed on dendritic cells, the effect of CIM on the antigen presenting ability of dendritic cells appears to increase because of CIMspecific actions (Fig. 1) (44). It also remains unclear whether or not the modulating effects of CIM on the dendritic cell function observed in vitro by Kubota and colleagues (44) have any clinically substantial meaning: the clinical effectiveness of CIM against gastrointestinal malignancies is considered to be due to the combined total of immunological and nonimmunological actions.

CIM has been reported as having better cell-mediated immunomodulation than other H2RAs such as famotidine and ranitidine, and the differences between CIM and other H2RAs might be due to their structures and/or affinities to $\mathrm{H} 2$ receptors $(22,36)$.

Immunologically based therapies for various types of cancers are improved by adjuvant CIM therapy (47). Interestingly enough, one study has reported that a small number of patients with metastatic renal cell carcinomas (5\%) responded with long-term remission to CIM monotherapy (19). But, immunologically based therapies for renal cell carcinomas or disseminated malignant melanomas have usually been combined with CIM and the contributions of CIM have not been adequately controlled $(17,20,48,49)$.

Inhibition of cancer cell migration and the development of liver metastasis. In vitro studies have demonstrated that CIM inhibits the adhesion of some breast (50) and colon (29) cancer cells to human umbilical cord cells, a process that is a crucial biological step in tumor neo-angiogenesis and, consequently, in tumor progression and metastasis. Tomita et al (38) have shown that CIM-induced angiogenesis inhibition suppresses the growth of colon cancer implants in syngeneic mice and is associated with a significant decrease in VEGF expression levels in tumor tissue and the serum of colon 38-bearing mice (Fig. 2). In the syngeneic murine colon cancer CMT93 model, CIM also significantly reduced the growth of the subcutaneously grafted tumor and neovascularization in the tumor (25). CIM at this dose had no effect on the in vitro proliferation of this cell line (25). The cancer cells' production of the vascular endothelial growth factor was not affected by CIM, whereas the vascular-like tube formation by endothelial cells in vitro was significantly impaired in the presence of CIM (Fig. 2) (25). Their findings suggest that CIM suppresses tumor growth, at least in part by inhibiting tumor-associated angiogenesis. One of the major classes of adhesion molecules present on the surface of endothelial cells includes selectins (51). The direct implication of P-selectin in endothelial cell migration has been reported previously (52) and we recently suggested a direct implication of E-selectin in human endothelial cell migration during tubulogenesis (53). Both E- and $\mathrm{P}$-selectins are induced in endothelial cells by proangiogenic cytokines such as the tumor necrosis factor (TNF)- $\alpha$ or IL-1ß (51). Since Kobayashi et al (29) have shown that CIM prevented liver metastasis of colon cancer cells in nude mice by blocking the E-selectin expression on the endothelial cells, the anti-angiogenic effect of CIM could also be related to the decrease in E-selectin expression on endothelial cells and therefore to its anti-metastatic effect against carcinoma cells invading the liver (Figs. 2 and 3). 
Kobayashi et al (29) have also shown that CIM (daily doses of $200 \mathrm{mg} / \mathrm{kg}$ ) prevented liver metastasis of colon cancer cells in nude mice by blocking E-selectin expression on the endothelial cells, a ligand for sialyl Lewis antigens on tumor cells (Fig. 3). Epithelial cells detaching themselves from primary epithelial tumors (carcinomas) and migrating through the lymphatic or the blood vessels (Fig. 3) eventually colonize the liver due to the fact that epithelial cancer cells exhibiting Lewis antigens [involving CD15 with fucose moieties, i.e. fucosyl-N-acetyl-lactosamine (fucosyl-LacNAc)] on their surface are able to adhere to endothelial cells in liver sinusoids because of the presence of selectins (the ligands for Lewis antigens) in these endothelial liver cells (Fig. 3) (13,54-56). Kaji et al (54) and Khatib et al (55) showed that upon entry into the hepatic circulation, epithelial tumor cells can rapidly trigger a molecular cascade (involving interleukin-1 secretion by tumor cells) leading to the induction of E-selectin expression on the sinusoidal endothelium (Fig. 3). Khatib et al (55) thus suggested that E-selectin induction in liver sinusoids by carcinoma cells contributes to the liver-colonizing potential of carcinoma cells (Fig. 3). Again, these actions of CIM probably do not occur via the blocking of the histamine receptor because famotidine and ranitidine did not show any similar effect. CIM treatment was particularly effective in colorectal cancer patients with tumors expressing higher levels of sialyl Lewis- $X$ and sialyl Lewis-A epitopes which are involved in E-selectin mediated cell adhesion with endothelial cells (13).

\section{Cimetidine and malignant gliomas}

Malignant gliomas are the most frequently encountered primary brain tumors in adults and children $(57,58)$; these malignant gliomas include neoplasms of astrocytic (anaplastic astrocytomas and glioblastomas) and oligodendroglial (anaplastic oligodendrogliomas) lineages (59). The standard treatment for these malignant gliomas is typically surgery, followed by radiotherapy and chemotherapy $(58,60-63)$. However, only those malignant gliomas that exhibit a loss of heterozygosity $(\mathrm{LOH})$ of chromosomes $1 \mathrm{p}$ and $19 \mathrm{q}$ are chemoresponsive $(64,65)$. Unfortunately, gliomas exhibiting 1p/19q LOH are mainly malignant oligodendrogliomas, i.e. a minor proportion of malignant gliomas $(59,66)$. In other words, most malignant gliomas are of astrocytic origin, without $1 \mathrm{p} / 19 \mathrm{q} \mathrm{LOH}$, and are therefore weakly sensitive to any type of chemotherapy if at all (58). Malignant gliomas are biologically heterogeneous and include sub-populations of proliferating and migrating cells $(58,67,68)$. While certain intracellular signaling pathways specifically control cell proliferation and/or apoptosis, other intracellular signaling pathways control cell migration $(58,68-71)$. For example, the CAS/Crk assembly serves as a 'molecular switch' for the induction of cell migration and appears to contribute to the invasive property of tumors (70). Moreover, accumulating evidence suggests invasive glioma cells associated with high levels of migration display a decreased proliferation rate and a relative resistance to apoptosis $(57,58,68,70,71)$, a feature that may contribute to chemotherapy and radiotherapy resistance (71). It is these migrating glioma cells that renders dismal the prognosis associated with high-grade malignant gliomas $(58,68)$. Because experimentally decreasing migration in apoptosis-resistant migrating tumor astrocytes restores sensitivity to apoptosis $(58,68)$ and thus to pro-apoptotic drugs, it would be interesting to elaborate new therapeutic strategies targeting migrating glioma cells. Cell migration includes very complex cellular and molecular processes in which at least three independent but highly coordinated biological steps are involved, i.e.: a) cell adhesion to specific components of the extracellular matrix (ECM) (72-74); b) modifications to the organization of the actin cytoskeleton (75-77); and c) the secretion of proteases (78). Gene-expression profiling has implicated numerous genes involved in glioma cell migration, and many of these genes relate to cell adhesion molecules that directly interact with specific ECM components (79-84). Gladson has detailed the molecular nature of ECM in gliomas (85), the crucial roles of which have been emphasized for the first time by Rutka and colleagues $(86,87)$ with respect to gliomas. Apart from integrins $(85,88,89)$, galectins $(75,90-92)$ also play a number of crucial roles in glioma cell migration. While integrins employ protein-protein interactions with ECM components, galectins use protein-carbohydrate interactions between themselves and ECM glycoproteins, with the core of carbohydrate ligands for the galectins being represented by LacNAc moieties, i.e. Lewis antigens without fucosylation (58). We have shown that the interactions between the oligosaccharide moieties present in the glioma ECM and cell adhesion molecules present on the surface of glioma cells play a number of major roles in glioma cell migration (75,90-93). Among these oligosaccharide moieties that play a number of major roles in glioma cell migration are fucose and lactose $(75,85,90-92,94)$.

One major target in the fight against glioma cell migration is connected with the successful decrease in protease expression by glioma cells (78). Another major target involves adhesion molecules and their ligand in the extracellular matrix. By example, tenascin, an integrin ligand, is overexpressed in the extracellular matrix of malignant gliomas when compared to low-grade gliomas and normal brain parenchyma (85), and clinical applications serve to specifically combat this particular feature of glioma cell migration (95).

Complementary to conventional chemotherapy, CIM has been used successfully to inhibit cancer cell migration of epithelial origins (carcinomas) towards the liver $(13,29)$. It should be remembered that metastatic implantation of epithelial cancers in the liver involves cancer cell-mediated oligosaccharide moiety (the fucose moiety present on Lewis antigens) interactions with cell adhesion molecules (selectins) present in liver microvasculatures $(13,29,56)$. In view of the fact that levels of expression of fucose binding activities in malignant gliomas differ in relation to the levels of malignancy (91) and that these receptor types could influence the levels of proliferation of human glioma cells (93), we postulated that addition of CIM to temozolomide treatment would improve survival of human glioblastoma orthotopic xenograft-bearing immunodeficient mice when compared to temozolomide therapy alone. We chose the human U373 model because it is of astrocytic origin, devoid of $1 \mathrm{p} / 19 \mathrm{q} \mathrm{LOH}$ and weakly sensitive to temozolomide (96), and the rat 9L sarcoma model because of its diffuse invasive abilities with respect to the brain parenchyma (97). We observed that combining CIM 
with temozolomide improved survival of the U373 orthotopic xenograft-bearing nude mice (21). However, human glioblastoma U373 cells do not express $\mathrm{H} 2$ receptors (98), an observation which again argues against the possibility of $\mathrm{H} 2$ receptors on tumor cells playing a role in the CIM-induced effects.

In vitro colorimetric MTT-based assay have revealed that cimetidine significantly decreased growth of both human U373 glioblastoma and rat 9L gliosarcoma cells at concentrations $\geq 100 \mu \mathrm{M}$ (21). Van der Ven and colleagues (99) and Finn and colleagues (100) had previously tested the growth-modulating effects of CIM on glioma cultures derived from human brain tumors. They observed that high dose $(1 \mathrm{mM})$ CIM induced inhibition of in vitro proliferation of gliomas, while lower concentrations $(1 \mu \mathrm{M})$ were less effective $(99,100)$. We observed that in vitro $0.1-1 \mu \mathrm{M}$ CIM significantly decreased migration of both U373 and 9L brain tumor cells (21). We also demonstrated that 30 daily intraperitoneal injections of $30 \mathrm{mg} / \mathrm{kg}$ CIM markedly decreased the percentage of 9L tumor cells exhibiting endogenous receptors for fucose moieties and the concentration of endogenous receptors for fucose moieties in 9L tumor cells (21). This CIM-mediated decrease in endogenous receptors for fucose moieties could partly explain the cimetidine-induced decrease in 9L (and also U373) tumor cell migration and, in turn, the in vivo benefit of adding cimetidine to temozolomide.

Fucose-containing glycans with potential clinical applications are hypothesized to combat the development of malignant gliomas. Indeed, it has long been known that under normal circumstances, the astrocyte number is kept constant in the mammalian central nervous system during adulthood and old age, as a result of the balance of division promoters and division inhibitors (101). Moreover, Nieto-Sampedro (102) identified the mitogen inhibitors as immunologically related to blood group oligosaccharides (i.e. Lewis antigen-related structures) and to glycan epitopes of the epidermal growth factor receptor. On the basis of these data, Aguilera et al (103) synthesized a family of oligosaccharides with a common Lewis-X-type structure, i.e. fucosyl-LacNAc-related structures, and these compounds are the source of a significant level of antiproliferative activity against malignant glioblastoma cells (104). Our recent study also revealed that CIM significantly decreased the expression of endogenous receptors for LacNAc moieties (21), knowing that such endogenous ligands involve, for example, different types of galectins whose levels of expression can be modulated by anti-inflammatory compounds (105-107). We defined the role played by galectin-1 on glioma cell migration features $(75,90)$. Thus, this CIM-induced decrease in endogenous ligands for LacNAc (and maybe galectin-1) can act synergistically with the CIM-induced decrease in endogenous receptors for fucose on both 9L and U373 tumor cell migration levels and on the benefit in vivo of adding CIM to temozolomide.

\section{Conclusions}

Cimetidine is a histamine receptor-type $\mathrm{H} 2$ blocker whose clinical usefulness was clearly demonstrated several decades ago in the treatment of peptic ulcer disease. More recently, cimetidine has been proven to be a useful adjunct in colon cancer chemotherapy because it delays the formation of liver metastasis. Cimetidine also displays anti-tumor effects in gastric and renal carcinomas, and in melanomas. Cimetidine can also act as an immunomodulator by enhancing the host's immune response to tumor cells. We have recently shown that combining CIM with temozolomide improved survival when compared to temozolomide alone in human glioblastoma orthotopic xenograft-bearing nude mice. As reviewed in the present report, various mechanisms of action can be associated with the beneficial therapeutic effects contributed by cimetidine in the case of experimental glioblastomas, a fact that should encourage clinical investigators to enter highly malignant gliomas to cimetidine-related clinical trials.

\section{Acknowledgements}

We thank Steven Decorte, the GSK Belgium Medical Advisor, for his help with the bibliography. R.K. is a Director of Research with the Fonds National de la Recherche Scientifique (FNRS, Belgium) and F.L. is a Clinical Research Fellow with the FNRS.

\section{References}

1. Somogyi A and Gugler R: Clinical pharmacokinetics of cimetidine. Clin Pharmacokinet 8: 463-495, 1983.

2. Brogden RN, Heel RC, Speight TM and Avery GS: Cimetidine: a review of its pharmacological properties and therapeutic efficacy in peptic ulcer disease. Drugs 15: 93-131, 1978.

3. Moller H, Lindvig K, Klefter R, Mosbech J and Moller Jensen O: Cancer occurrence in a cohort of patients treated with cimetidine. Gut 30: 1558-1562, 1989.

4. Streett CS, Cimprich RE and Robertson JL: Pathologic findings in the stomachs of rats treated with the H2-receptor antagonist tiotidine. Scand J Gastroenterol Suppl 101: 109-117, 1984.

5. Burtin C, Noirot C, Scheinmann P, Galoppin L, Sabolovic D and Bernard P: Clinical improvement in advanced cancer disease after treatment combining histamine and $\mathrm{H} 2$-antihistaminics (ranitidine or cimetidine). Eur J Cancer Clin Oncol 24: 161-167, 1988.

6. Tonnesen H, Knigge U, Bulow S, Damm P, Fischerman K, Hesselfeldt P, Hjortrup A, Pedersen IK, Pedersen VM, Siemssen OJ, et al: Effect of cimetidine on survival after gastric cancer. Lancet ii: 990-992, 1988.

7. Adams WJ and Morris DL: Short-course cimetidine and survival with colorectal cancer. Lancet 344: 1768-1769, 1994.

8. Matsumoto S: Cimetidine and survival with colorectal cancer. Lancet 346: 115, 1995.

9. Svendsen LB, Ross C, Knigge U, Frederiksen HJ, Graversen P, Kjaergard J, Luke M, Stimpel H and Sparso BH: Cimetidine as an adjuvant treatment in colorectal cancer. A double-blind, randomized pilot study. Dis Colon Rectum 38: 514-518, 1995.

10. Adams WJ and Morris DL: Pilot study - cimetidine enhances lymphocyte infiltration of human colorectal carcinoma: results of a small randomized control trial. Cancer 80: 15-21, 1997.

11. Kelly MD, King J, Cherian M, Dwerryhouse SJ, Finlay IG, Adams WJ, King DW, Lubowski DZ and Morris DL: Randomized trial of preoperative cimetidine in patients with colorectal carcinoma with quantitative assessment of tumorassociated lymphocytes. Cancer 85: 1658-1663, 1999.

12. Bolton E, King J and Morris DL: H2-antagonists in the treatment of colon and breast cancer. Semin Cancer Biol 10: 3-10, 2000.

13. Matsumoto S, Imaeda Y, Umemoto S, Kobayashi K, Suzuki H and Okamoto T: Cimetidine increases survival of colorectal cancer patients with high levels of sialyl Lewis-X and sialyl Lewis-A epitope expression on tumour cells. Br J Cancer 86: 161-167, 2002.

14. Hellstrand K, Naredi P, Lindner P, Lundholm K, Rudenstam CM, Hermodsson S, Asztely M and Hafstrom L: Histamine in immunotherapy of advanced melanoma: a pilot study. Cancer Immunol Immunother 39: 416-419, 1994. 
15. Creagan ET, Ahmann DL, Green SJ, Long HJ, Frytak S and Itri LM: Phase II study of recombinant leukocyte A interferon (IFN-rA) plus cimetidine in disseminated malignant melanoma. J Clin Oncol 3: 977-981, 1985.

16. Morton RF, Creagan ET, Cullinan SA, Mailliard JA, Ebbert L, Veeder $\mathrm{MH}$ and Chang $\mathrm{M}$ : Phase II studies of single-agent cimetidine and the combination N-phosphonacetyl-L-aspartate (NSC-224131) plus L-alanosine (NSC-153353) in advanced malignant melanoma. J Clin Oncol 5: 1078-1082, 1987.

17. Marshall ME, Mendelsohn L, Butler K, Riley L, Cantrell J, Wiseman C, Taylor R and MacDonald JS: Treatment of metastatic renal cell carcinoma with coumarin (1,2-benzopyrone) and cimetidine: a pilot study. J Clin Oncol 5: 862-866, 1987.

18. Dexeus FH, Logothetis CJ, Sella A, Fitz K, Amato R, Reuben JM and Dozier N: Phase II study of coumarin and cimetidine in patients with metastatic renal cell carcinoma. J Clin Oncol 8: 325-329, 1990.

19. Inhorn L, Williams SD, Nattam S and Stephens D: High-dose cimetidine for the treatment of metastatic renal cell carcinoma. A Hoosier Oncology Group study. Am J Clin Oncol 15: 157-159, 1992.

20. Sagaster P, Micksche M, Flamm J and Ludwig H: Randomised study using IFN-alpha versus IFN-alpha plus coumarin and cimetidine for treatment of advanced renal cell cancer. Ann Oncol 6: 999-1003, 1995.

21. Lefranc F, James S, Camby I, Gaussin JF, Darro F, Brotchi J, Gabius J and Kiss R: Combined cimetidine and temozolomide, compared with temozolomide alone: significant increases in survival in nude mice bearing U373 human glioblastoma multiforme orthotopic xenografts. J Neurosurg 102: 706-714, 2005.

22. Morris DL and Adams WJ: Cimetidine and colorectal cancer - old drug, new use? Nat Med 1: 1243-1244, 1995.

23. Adams WJ, Lawson JA and Morris DL: Cimetidine inhibits in vivo growth of human colon cancer and reverses histamine stimulated in vitro and in vivo growth. Gut 35: 1632-1636, 1994.

24. Reynolds JL, Akhter J and Morris DL: In vitro effect of histamine and histamine $\mathrm{H} 1$ and $\mathrm{H} 2 \mathrm{RAs}$ on cellular proliferation of human malignant melanoma cell lines. Melanoma Res 6: 95-99, 1996.

25. Natori T, Sata M, Nagai R and Makuuchi M: Cimetidine inhibits angiogenesis and suppresses tumor growth. Biomed Pharmacother 59: 56-60, 2005.

26. Osband ME, Hamilton D, Shen YJ, Cohen E, Shlesinger M, Lavin P, Brown A and McCaffrey R: Successful tumour immunotherapy with cimetidine in mice. Lancet i: 636-638, 1981.

27. Hellstrand $\mathrm{K}$ and Hermodsson S: Histamine H2-receptor-mediated regulation of human natural killer cell activity. J Immunol 137: 656-660, 1986.

28. Gifford RR and Tilberg AF: Histamine type-2 receptor antagonist immune modulation. II. Cimetidine and ranitidine increase interleukin-2 production. Surgery 102: 242-247, 1987.

29. Kobayashi K, Matsumoto S, Morishima T, Kawabe T and Okamoto T: Cimetidine inhibits cancer cell adhesion to endothelial cells and prevents metastasis by blocking E-selectin expression. Cancer Res 60: 3978-3984, 2000.

30. Watson SA, Wilkinson LJ, Robertson JF and Hardcastle JD: Effect of histamine on the growth of human gastrointestinal tumours: reversal by cimetidine. Gut 34: 1091-1096, 1993.

31. Hahm KB, Park IS, Kim HC, Lee KJ, Kim JH, Cho SW and Lee SI: Comparison of antiproliferative effects of 1-histamine-2 receptor antagonists, cimetidine, ranitidine and famotidine, in gastric cancer cells. Int J Immunopharmacol 18: 393-399, 1996.

32. Rajendra S, Mulcahy H, Patchett S and Kumar P: The effect of $\mathrm{H} 2$ antagonists on proliferation and apoptosis in human colorectal cancer cell lines. Dig Dis Sci 49: 1634-1640, 2004.

33. Surucu O, Middeke M, Hoschele I, Kalder J, Hennig S, Dietz C and Celik I: Tumour growth inhibition of human pancreatic cancer xenografts in SCID mice by cimetidine. Inflamm Res 53 (Suppl 1): S39-S40, 2004.

34. Takahashi K, Tanaka S, Furuta K and Ichikawa A: Histamine $\mathrm{H}(2)$ receptor-mediated modulation of local cytokine expression in a mouse experimental tumor model. Biochem Biophys Res Commun 297: 1205-1210, 2002.

35. Takahashi K, Tanaka S and Ichikawa A: Effect of cimetidine on intratumoral cytokine expression in an experimental tumor. Biochem Biophys Res Commun 281: 1113-1119, 2001.

36. Lawson JA, Adams WJ and Morris DL: Ranitidine and cimetidine differ in their in vitro and in vivo effects on human colonic cancer growth. Br J Cancer 73: 872-876, 1996.
37. Primrose JN, Miller GV, Preston SR, Gokhale J, Ambrose NS, Ward UM, Mills JG, Ehsanullah RS and Darekar B: A prospective randomised controlled study of the use of ranitidine in patients with gastric cancer. Yorkshire GI Tumour Group. Gut 42: 17-19, 1998 .

38. Tomita K, Izumi K and Okabe S: Roxatidine- and cimetidineinduced angiogenesis inhibition suppresses growth of colon cancer implants in syngeneic mice. J Pharmacol Sci 93: 321-330, 2003.

39. Szincsak N, Hegyesi H, Hunyadi J, Falus A and Juhasz I: Different $\mathrm{h} 2$ receptor antihistamines dissimilarly retard the growth of xenografted human melanoma cells in immunodeficient mice. Cell Biol Int 26: 833-836, 2002.

40. Garcia-Caballero M, Nunezed X, Castro I, Kusche J and VoraThorbeck L: Histamine metabolism in human breast and colorectal cancer: its effects on other host tissues. Adv Biosci 89: 273-287, 1993.

41. Nishiguchi S, Tamori A, Shiomi S, Enomoto M, Tatsumi N, Koh N, Habu D, Sakaguchi H, Takeda T, Seki S, et al: Cimetidine reduces impairment of cellular immunity after transcatheter arterial embolization in patients with hepatocellular carcinoma. Hepatogastroenterology 50: 460-462, 2003.

42. Hahm KB, Lee SI, Chung JP, Kim WH, Kim JH and Park IS: Comparison of immunomodulative effects of histamine-2 receptor antagonists in gastric cancer patients: focus on the lymphoblastogenesis and cytotoxicity of peripheral blood mononuclear cells. Int J Immunopharmacol 16: 985-993, 1994.

43. Lin CY, Bai DJ, Yuan HY, Wang K, Yang GL, Hu MB, Wu ZQ and Li Y: Perioperative cimetidine administration promotes peripheral blood lymphocytes and tumor infiltrating lymphocytes in patients with gastrointestinal cancer: results of a randomized controlled clinical trial. World J Gastroenterol 10: 136-142, 2004.

44. Kubota T, Fujiwara H, Ueda Y, Itoh T, Yamashita T, Yoshimura T, Okugawa K, Yamamoto Y, Yano Y and Yamagishi H: Cimetidine modulates the antigen presenting capacity of dendritic cells from colorectal cancer patients. $\mathrm{Br}$ J Cancer 86: 1257-1261, 2002.

45. Horvath BV, Szalai C, Mandi Y, Laszlo V, Radvany Z, Darvas Z and Falus A: Histamine and histamine-receptor antagonists modify gene expression and biosynthesis of interferon gamma in peripheral human blood mononuclear cells and in CD19depleted cell subsets. Immunol Lett 70: 95-99, 1999.

46. Elenkov IJ, Webster E, Papanicolaou DA, Fleisher TA, Chrousos GP and Wilder RL: Histamine potently suppresses human IL-12 and stimulates IL-10 production via H2 receptors. J Immunol 161: 2586-2593, 1998.

47. Smith T: Histamine type 2-receptor antagonists and cancer immunotherapy. Compr Ther 16: 8-13, 1990.

48. Creagan ET, Schaid DJ, Ahmann DL and Frytak S: Disseminated malignant melanoma and recombinant interferon: analysis of seven consecutive phase II investigations. J Invest Dermatol 95: 188S-192S, 1990.

49. Kinouchi T, Saiki S, Maeda O, Kuroda M, Usami M and Kotake T: Treatment of advanced renal cell carcinoma with a combination of human lymphoblastoid interferon-alpha and cimetidine. J Urol 157: 1604-1607, 1997.

50. Bobek V, Boubelik M, Kovarik J and Taltynov O: Inhibition of adhesion breast cancer cells by anticoagulant drugs and cimetidine. Neoplasma 50: 148-151, 2003.

51. Vestweber D and Blanks JE: Mechanisms that regulate the function of the selectins and their ligands. Physiol Rev 79: 181-213, 1999.

52. Morbidelli L, Brogelli L, Crancer HJ and Ziche M: Endothelial cell migration is induced by soluble P-selectin. Life Sci 62: 7-11, 1998.

53. Lefranc F, Mijatovic T, Mathieu V, Rorive S, Decaestecker C, Debeir O, Brotchi J, van Ham P, Salmon I and Kiss R: Characterization of gastrin-induced proangiogenic effects in vivo in orthotopic U373 experimental human glioblastomas and in vitro in human umbilical vein endothelial cells. Clin Cancer Res 10: 8250-8265, 2004.

54. Kaji M, Ishikura H, Kishimoto T, Omi M, Ishizu A, Kimura C, Takahashi T, Kato $\mathrm{H}$ and Yoshiki T: E-selectin expression induced by pancreas-carcinoma-derived interleukin- 1 alpha results in enhanced adhesion of pancreas-carcinoma cells to endothelial cells. Int J Cancer 60: 712-717, 1995.

55. Khatib AM, Kontogiannea M, Fallavollita L, Jamison B, Meterissian S and Brodt P: Rapid induction of cytokine and E-selectin expression in the liver in response to metastatic tumor cells. Cancer Res 59: 1356-1361, 1999. 
56. Weston BW, Hiller KM, Mayben JP, Manousos GA, Bendt KM, Liu R and Cusack JC Jr: Expression of human alpha(1,3)fucosyltransferase antisense sequences inhibits selectin-mediated adhesion and liver metastasis of colon carcinoma cells. Cancer Res 59: 2127-2135, 1999.

57. Burton EC and Prados MD: Malignant gliomas. Curr Treat Option Oncol 1: 459-468, 2000.

58. Lefranc F, Brotchi J and Kiss R: Possible future issues in the treatment of glioblastomas: special emphasis on cell migration and the resistance of migrating glioblastoma cells to apoptosis. J Clin Oncol 23: 2411-2422, 2005.

59. Kleihues P and Cavenee WK: Pathology and Genetics of Tumours of the Nervous System. International Agency for Research on Cancer (IARC). WHO Health Organisation, Oxford. IARC Press, Lyon, 2000.

60. Brandes AA: State-of-the-art treatment of high-grade brain tumors. Semin Oncol 30: 4-9, 2003.

61. De Angelis LM: Benefits of adjuvant chemotherapy in highgrade gliomas. Semin Oncol 30: 15-18, 2003.

62. Laws ER, Parney IF, Huang W, Anderson F, Morris AM, Asher A, Lillehei KO, Bernstein M, Brem H, Sloan A, et al: Survival following surgery and prognostic factors for recently diagnosed malignant glioma: data from the Glioma Outcomes Project. J Neurosurg 99: 467-473, 2003.

63. MacDonald DR: New frontiers in the treatment of malignant glioma. Semin Oncol 30: 72-76, 2003.

64. Bigner SH, Matthews MR, Rasheed BK, Wiltshire RN, Friedman HS, Friedman AH, Stenzel TT, Dawes DM, McLendon RE and Bigner DD: Molecular genetic aspects of oligodendrogliomas including analysis by comparative genomic hybridization. Am J Pathol 155: 375-386, 1999.

65. Cairncross JG, Ueki K, Zlatescu MC, Lisle DK, Finkelstein DM, Hammond RR, Silver JS, Stark PC, MacDonald DR, Ino Y, et al: Specific genetic predictors of chemotherapeutic response and survival in patients with anaplastic oligodendrogliomas. J Natl Cancer Inst 90: 1473-1479, 1998

66. Nutt CL, Mani DR, Betensky RA, Tamayo P, Cairncross JG, Ladd C, Pohl U, Hartmann C, McLaughlin ME, Batchelor TT, et al: Gene expression-based classification of malignant gliomas correlates better with survival than histological classification. Cancer Res 63: 1602-1607, 2003

67. Dunn IF and Black PM: The neurosurgeon as local oncologist: cellular and molecular neurosurgery in malignant glioma therapy. Neurosurgery 52: 1411-1422, 2003.

68. Giese A, Bjerkvig R, Berens ME and Westphal M: Cost of migration: invasion of malignant gliomas and implications for treatment. J Clin Oncol 21: 1624-1636, 2003.

69. Belien AT, Paganetti PA and Schwab ME: Membrane-type 1 matrix metalloprotease (MT1-MMP) enables invasive migration of glioma cells in central nervous system white matter. J Cell Biol 144: 373-384, 1999.

70. Klemke RL, Leng J, Molander R, Brooks PC, Vuori K and Cheresh DA: CAS/Crk coupling serves as a 'molecular switch' for induction of cell migration. J Cell Biol 140: 961-972, 1998.

71. Puchner MJ and Giese A: Tamoxifen-resistant glioma-cell subpopulations are characterized by increased migration and proliferation. Int J Cancer 86: 468-473, 2000

72. Giancotti FG and Ruoslahti E: Integrin signaling. Science 285: $1028-1032,1999$

73. Hood JD and Cheresh DA: Role of integrins in cell invasion and migration. Nat Rev Cancer 2: 91-100, 2002.

74. Palecek SP, Loftus JC, Ginsberg MH, Lauffenburger DA and Horwitz AF: Integrin-ligand binding properties govern cell migration speed through cell-substratum adhesiveness. Nature 385: 537-540, 1997

75. Camby I, Belot N, Lefranc F, Sadeghi N, De Launoit Y, Kaltner H, Musette S, Darro F, Danguy A, Salmon I, et al: Galectin-1 modulates human glioblastoma cell migration into the brain through modifications to the actin cytoskeleton and levels of expression of small GTPases. J Neuropathol Exp Neurol 61: 585-596, 2002.

76. Lefranc F, Camby I, Belot N, Bruyneel E, Chaboteaux C, Brotchi J, Mareel M, Salmon I and Kiss R: Gastrin significantly modifies the migratory abilities of experimental glioma cells. Lab Invest 82: 1241-1252, 2002.

77. Raftopoulou M and Hall A: Cell migration: Rho GTPases lead the way. Dev Biol 265: 23-32, 2004.

78. Rao JS: Molecular mechanisms of glioma invasiveness: the role of proteases. Nat Rev Cancer 3: 489-501, 2003.
79. Kucharczak J, Pannequin J, Camby I, Decaestecker C, Kiss R and Martinez J: Gastrin induces over-expression of genes involved in human U373 glioblastoma cell migration. Oncogene 20: 7021-7028, 2001

80. Mariani L, McDonough WS, Hoelzinger DB, Beaudry C Kaczmarek E, Coons SW, Giese A, Moghaddam M, Seiler RW and Berens ME: Identification and validation of P311 as a glioblastoma invasion gene using laser capture microdissection. Cancer Res 61: 4190-4196, 2001.

81. Rickman DS, Bobek MP, Misek DE, Kuick R, Blaivas M, Kurnit DM, Taylor J and Hanash SM: Distinctive molecular profiles of high-grade and low-grade gliomas based on oligonucleotide microarray analysis. Cancer Res 61: 6885-6891, 2001.

82. Tatenhorst L, Senner V, Puttmann S and Paulus W: Regulators of G-protein signaling 3 and 4 (RGS3, RGS4) are associated with glioma cell motility. J Neuropathol Exp Neurol 63: 210-222, 2004

83. Hoelzinger DB, Mariani L, Weis J, Woyke T, Berens TJ, McDonough WS, Sloan A, Coons SW and Berens ME: Gene expression profile of glioblastoma multiforme invasive phenotype points new therapeutic targets. Neoplasia 1: 7-16, 2005.

84. Paulus W, Baur I, Dours-Zimmermann MT and Zimmermann DR Differential expression of versican isoforms in brain tumors. J Neuropathol Exp Neurol 55: 528-533, 1996.

85. Gladson CL: The extracellular matrix of gliomas: modulation of cell function. J Neuropathol Exp Neurol 58: 1029-1040, 1999.

86. Rutka JT, Apodaca G, Stern R and Rosenblum M: The extracellular matrix of the central and peripheral nervous systems: structure and function. J Neurosurg 69: 155-170, 1988.

87. Rutka JT, Myatt CA, Giblin JR, Davis RL and Rosenblum ML: Distribution of extracellular matrix proteins in primary human brain tumours: an immunohistochemical analysis. Can J Neurol Sci 14: 25-30, 1987

88. Kanamori M, van den Berg SR, Bergers G, Berger MS and Pieper RO: Integrin beta3 overexpression suppresses tumor growth in a human model of gliomagenesis: implications for the role of beta3 overexpression in glioblastoma multiforme. Cancer Res 64: 2751-2758, 2004

89. Paulus W, Baur I, Schuppan D and Roggendorf W: Characterization of integrin receptors in normal and neoplastic human brain. Am J Pathol 143: 154-163, 1993.

90. Camby I, Belot N, Rorive S, Lefranc F, Maurage CA, Lahm H, Kaltner H, Hadari Y, Ruchoux MM, Brotchi J, et al: Galectins are differentially expressed in supratentorial pilocytic astrocytomas, astrocytomas, anaplastic astrocytomas and glioblastomas and significantly modulate tumor astrocyte migration. Brain Pathol 11: 12-26, 2001

91. Camby I, Decaestecker C, Gordower L, De Decker R, Kacem Y, Lemmers A, Siebert HC, Bovin NV, Wesseling P, Danguy A, et al: Distinct differences in binding capacity to saccharide epitopes in supratentorial pilocytic astrocytomas, astrocytomas, anaplastic astrocytomas and glioblastomas. J Neuropathol Exp Neurol 60: 75-84, 2001

92. Camby I, Decaestecker C, Lefranc F, Kaltner H, Gabius HJ and Kiss R: Galectin-1 knocking down in human U87 glioblastoma cells alters their gene expression pattern. Biochem Biophys Res Commun 335: 27-35, 2005

93. Camby I, Salmon I, De Decker R, Pasteels JL, Brotchi J, Danguy A and Kiss R: Lectin histochemistry of astrocytic tumors and in vitro characterization of lectin-induced modifications on the proliferation of the SW1088, U373 and U87 human astrocytic cell lines. J Neurooncol 34: 111-122, 1997.

94. Yates AJ, Comas T, Scheithauer BW, Burger PC and Pearl DK Glycolipid markers of astrocytomas and oligodendrogliomas. J Neuropathol Exp Neurol 58: 1250-1262, 1999.

95. Reardon DA, Akabani G, Coleman RE, Friedman AH, Friedman HS, Herndon JE II, Cokgor I, McLendon RE, Pegram CN, Provenzale JM, et al: Phase II trial of murine (131)I-labeled antitenascin monoclonal antibody 81C6 administered into surgically created resection cavities of patients with newly diagnosed malignant gliomas. J Clin Oncol 20: 1389-1397, 2002.

96. Branle F, Lefranc F, Camby I, Jeuken J, Geurts-Moespot A, Sprenger S, Sweep F, Kiss R and Salmon I: Evaluation of the efficiency of chemotherapy in in vivo orthotopic models of human glioma cells with and without 1p19q deletions and in C6 rat orthotopic allografts serving for the evaluation of surgery combined with chemotherapy. Cancer 95: 641-655, 2002. 
97. Lefranc F, Sadeghi N, Metens T, Brotchi J, Salmon I and Kiss R: Characterization of gastrin-induced cytostatic effect on cell proliferation in experimental malignant gliomas. Neurosurgery 52: 881-890, 2003.

98. Hernandez-Angeles A, Soria-Jasso LE, Ortega A and AriasMontano JA: Histamine H1 receptor activation stimulates mitogenesis in human astrocytoma U373 MG cells. J Neurooncol 55: 81-89, 2001

99. Van der Ven LT, Prinsen IM, Jansen GH, Roholl PJ, Defferrari R, Slater R and den Otter W: Growth of cultured human glioma tumour cells can be regulated with histamine and histamine antagonists. Br J Cancer 68: 475-483, 1993.

100. Finn PE, Purnell P and Pilkington GJ: Effect of histamine and the $\mathrm{H} 2$ antagonist cimetidine on the growth and migration of human neoplastic glia. Neuropathol Appl Neurobiol 22: 317-324, 1996.

101. Korr H: Proliferation and cell cycle parameters of astrocytes. In: Astrocytes. Vol. 3. Fedoroff S and Vernadakis A (eds). Academic Press Inc. Ltd., London, pp77-127, 1986.

102. Nieto-Sampedro M: Astrocyte mitogen inhibitor related to epidermal growth factor receptor. Science 240: 1784-1785, 1988.
103. Aguilera B, Romero-Ramirez L, Abad-Rodriguez J, Corrales G, Nieto-Sampedro $M$ and Fernandez-Mayoralas A: Novel disaccharide inhibitors of human glioma cell division. J Med Chem 41: 4599-4606, 1998.

104. Nieto-Sampedro M, Bailon C, Fernandez-Mayoralas A, Martin-Lomas M, Mellstrom B and Naranjo JR: Experimental brain glioma: growth arrest and destruction by a blood-grouprelated tetrasaccharide. J Neuropathol Exp Neurol 55: 169-177, 1996.

105. Chiariotti L, Salvatore P, Frunzio R and Bruni CB: Galectin genes: regulation of expression. Glycoconj J 19: 441-449, 2004.

106. Delbrouck C, Doyen I, Belot N, Decaestecker C, Ghanooni R, De Lavareille A, Kaltner H, Choufani G, Danguy A, van den Hoven $\mathrm{G}$, et al: Galectin-1 is overexpressed in nasal polyps under budesonide and inhibits eosinophil migration. Lab Invest 82: 147-158, 2002.

107. Gitt MA and Barondes SH: Genomic sequence and organization of two members of a human lectin gene family. Biochemistry 30: 82-89, 1991. 